\title{
INCORPORATING ROLE OF STAKEHOLDERS INTO CORPORATE CSR STRATEGY FOR SUSTAINABLE GROWTH: AN EXPLORATORY STUDY
}

\author{
Vani Tanggamani*, Siti Anis Nadia Abu Bakar, Rani Diana Othman \\ Faculty of Accountancy, Universiti Teknologi MARA Melaka
}

\begin{abstract}
In today's modern day context, Corporate Social Responsibility (CSR) become the mantra for businesses as it can be seen as a strategic approach for firms to be succeed in their business endeavours. Hence, it remains the most widely used concept to refer to organizationalstakeholder relationships. An understanding about a stakeholder approach to CSR is an important means for a firm to enhance their commitment to operate in an economically, socially and environmentally sustainable manner. In support with above arguments, this article presents a theoretical proposition based on stakeholder theory for better CSR and firm performance. By drawing upon classic work in the field, the paper offers conceptual discussion and then systematically develops a means of stakeholder approach into corporate CSR strategy. The aim of this paper is to demonstrates the need for a firm to enhance further understanding about the role of stakeholders in the context of corporate CSR strategy, which is increasingly necessary in view of the fact that business entities are absolutely essential for economic development, but at the same time, their business activities pose a huge impact to society and the environment. Thus, firm's CSR disclosure is a pivotal tool to establish a relationship of working together with the stakeholders that ensures mutual benefit and continue to be a firm that is needed by society. This article contributes to the literature by providing a fundamental explanation of how a business should embrace responsibility for the impact of its activities on the stakeholders across various levels of the value chain. By doing so, firms are offered a means to take a much more proactive approach to CSR through the stakeholder approach which is precisely helpful in measuring the effectiveness of any CSR initiative on the society to foster business sustainability.
\end{abstract}

Keywords: Corporate Social Responsibility, Stakeholder Relationships, Stakeholder Theory

\section{INTRODUCTION}

The concept of Corporate Social Responsibility (CSR) remains open to various definitions and understanding (Lu, 2013). However, in line with the literatures definition of CSR, it can be concluded that CSR is a firm's obligation and accountability for incorporating social and environmental responsibilities into the business decision-making process as well as to use its resources in ways to contribute to the well being of society (Caroll, 1979; Gill, 2008; Caroll \& Shabana, 2010).

Despite its controversial nature, CSR has become an avid interest of the millennial generation within the business world, mainly due to globalization. Until the late 1970s, CSR was derided as a joke, an oxymoron and a contradiction in terms of the investment and by the business community (Whalen, 2013; Lu, Chau, Wang \& Pan, 2014). However, as for now, CSR become 
the mantra for businesses to ensure that the company stays in business for a long time to come (Ditlev-Simonsen \& Midttun, 2011).

Today's businesses are under increasing pressure to demonstrate and integrate their core financial operations with the engagement of social and environmental concerns for the benefit of its stakeholders (Amran, 2006; Pop,O.et al, 2011), in order to develop a sustainable and true presence (Chen, Feldmann, \& Tang, 2015). Thus, the overall demand has driven many companies that are currently practicing corporate social responsibility. Hence, the business's purpose now is not only to earn profit but the welfare of the society as well (Zhu, 2011). Therefore, the question that firm ask now days is not "why should we get involved in CSR?" but rather "how should we do it?" and "how can we benefit the environment and contribute to the community?" (Ghotb, 2011). As a result, CSR is getting famous and business organisations are gradually more concerned with the way they operate their business and the impact of their action on society and environment ( $\mathrm{Lu}, 2014)$.

During this era, CSR is an action tool of top management for long-term success, as described in earlier research by Gray, Owen and Adams (1996), since many corporate organisations believe that success with CSR strategies will lead to success in organisation performance too, as it constitutes a benefit not only to the society but to the business itself also (Ditlev-Simonsen \& Midttun, 2011; DiSegni, Huly, \& Akron, 2015). Hence, a larger number of companies are engaged in a serious effort to define and integrate CSR strategies into all aspects of their businesses due to the globalization (Chen et al., 2015).

\section{CSR and Stakeholder Relationships}

Businesses are an essential part of the communities in which they operate (Belkaoui, 2000; Dkhili \& Ansi, 2012). Good management know that their long-term success is based on continued good relations with a wide range of stakeholders because business can't succeed in societies that are failing due to social or environmental challenges ( $\mathrm{Zhu}, 2011$ ). As a result, when operate in businesses in present environment, the most important area that firms must concern is businesses are under increasing pressure to demonstrably engage in activities which are described as CSR.

CSR is the firm's social responsibility that gives a picture of how a firm take charge of their business processes in order to produce an overall positive impact to the society (Neal \& Cochran, 2008). As such, firm's responsibility extends beyond the shareholders as it does not operate in isolation of its surrounding, namely the society and the environment. In fact, business success is increasingly affected by stakeholder relationships, which covers a wide range of interests, the most pivotal of which being how the organisation works with social and environmental issues (Gray et al., 1996; Russo \& Perini, 2010).

This implying that firm should concern with the society ethically and not only pays attention to their profit, and also should more care about their stakeholders' expectations and what they are desired for. This is due to the fact that most of the investors are invest in firms that have involve greatly in CSR activities (Raza, Ilyas, Rauf \& Qamar, 2012). As a result, corporations have adopted the concept of CSR, in fact, the corporation's concern is seen to be shifting to broader components of CSR, which includes stakeholders as one of the most important focus (Carroll, 1979; Gray et al., 1996; Orlitzky, Schmidt \& Rynes, 2003; Amran, Zain, Sulaiman, Sarker \& Ooi, 2013). 
In a nutshell, CSR disclosure is becoming as an important tool to maintain the positive relationship with stakeholders (Esa \& Mohd Ghazali, 2012) in view of the fact that the satisfaction of all stakeholders enhances the image and reputation of the company, thus improving the financial performance (Freeman, 1984; Donaldson \& Preston, 1995). Strategically speaking, business can only flourish when the CSR program is implemented effectively because CSR is essential resource for a firm to improve their stakeholders relationships.

\section{Stakeholder Theory}

Stakeholder theory, as introduced by Freeman (1984), has been analysed exclusively from the perspective of an organisation (Amran et al, 2013). This theory has been used as a tool to identify those stakeholders to whom an organisation should be accountable as to recognises their rights. Accordingly, Freeman (1984) defines a stakeholder as "any group or individual who can affect or is affected by the achievement of the organisation's objectives" (p. 46). Similarly, Murray and Vogel (1997), define stakeholder as any entity, typically outside the firm, that the organisation aims to influence and that has an impact on the organisation.

The aim of this theory is to develop a CSR framework using stakeholders due to the fact that stakeholders are recognised as the group of people interested in the company's activities (Freeman, 1984). Therefore, stakeholder theory suggests that the purpose of a business should be to create as much value as possible for stakeholders and ensure the expectations of stakeholders aligned and going in the same direction (O'Riordan \& Fairbrass, 2008). In this regard, Table 1.1 illustrates the primary stakeholders in an organisation and their most important objectives or expectations. By knowing this, a firm would be possible to develop business operations in tune with the frame of reference in which the firm operates.

Table 1:Stakeholders in the organisation and their objectives or expectations.

\begin{tabular}{cl}
\hline Stakeholder & Objectives \\
\hline Management & Governance, corporate culture, strategies, and overall performance \\
Shareholders & Profit, and the value of the stock in the stock market \\
Customers & Characteristics of the product and quality of services \\
Government & Security of society, sovereignty, respect for the laws, and paying taxes \\
Community & Environmental and social effects \\
Employees & Fairly compensated employment, working conditions, and job satisfaction \\
Suppliers & Price and volume of procurement, and sustainability \\
Banks & Payment systems and their flexibility \\
Investors & Information about the liquidity and viability of payment \\
\hline
\end{tabular}

Source: Adapted from Caroll, 1979; Clarkson, 1995; Cramer \& Bergmans, 2003

A stakeholder approach to CSR suggests that the expectations of all primary stakeholders need to be met, and not just the shareholders (Elijido-Ten, 2007). This practically means an organisation must be able to combine the profit maximization with all stakeholder's benefits and expectations in order to draw a complete map of all these relationships as to have a clearer view of all the needs of its stakeholders (Freeman, 1984). Accordingly, stakeholder theory has been applied to explain the motivations of firms regarding CSR disclosure (Freeman, 1984; Donaldson \& Preston, 1995; McWilliams \& Siegel, 2001; Abd Mutalib, Muhammad Jamil \& 
Wan Hussin, 2014). Under the umbrella of CSR, the firm is expected to fulfil its responsibility to its primary stakeholders (Vormedal \& Ruud, 2009; Hamid \& Atan, 2011; Amran et al, 2013). As a result, firm's CSR disclosure has been used as a strategy to maintain the support of powerful stakeholders (Deegan \& Blomquist, 2006). This implies that CSR represents an important element between the organisation and its stakeholders relationship (Murray \& Vogel, 1997; Elijido-Ten, 2007).

In sum, stakeholder theory proposes that CSR performance results in improved firm performance (Orlitzky et al., 2003; Freeman, 2010). Therefore, organisations need to identify and prioritise their stakeholders' expectations through their business operation (Clifton \& Azlan, 2010; Amran et al., 2013). In this respect, organisations must be able to secure their relationship with all stakeholders consistently, especially when they make CSR disclosure decision (Ahamed et al., 2014) since different stakeholders may have different impact on organisations.

\section{How Do Firms Benefit?}

CSR is concerned about dealing with the stakeholders of the firm ethically or in a socially responsible way. Stakeholders exist in a firm and outside of it (Hopkins, 1998). The stakeholder theory does take into account the wider consequences of the society (Freeman, 1984), thus, examine the nature of the CSR adoption and its link with the performance of the firm. Gyves and Higgins, (2008) have said that the relationship between CSR and firm performance really depends on how CSR is managed. Therefore, multiple stakeholder groups must be managed effectively for the well-being of the firm.

According to stakeholder theory, the satisfaction of various stakeholder groups is instrumental for a firm's performance (Donaldson \& Preston, 1995). The rationale on why CSR affects firm performance is because a firm's social involvements signal the firm's genuine care and concern for the welfare of its stakeholders, including investors, employees, suppliers, customers, and the society at large. This public image helps build long-term relationships with those stakeholders, facilitating cooperation with and support from them, which in turn contributes to a higher level of firm performance. Indeed, the firm cannot continue to flourish and survive without the support of stakeholders (Freeman, 1984), therefore, this study utilises stakeholder theory as the governing theory to explain the relationship between CSR and firm's stakeholder, as depicted in Figure 1.1, since firms involved continuously in activities of CSR with stakeholders (Jones, 1995) on the basis of trust and cooperation. 


\section{Figure 1}

Focus of the Study: Scheme of the relationship between CSR and Firm Stakeholder according to Stakeholder Theory

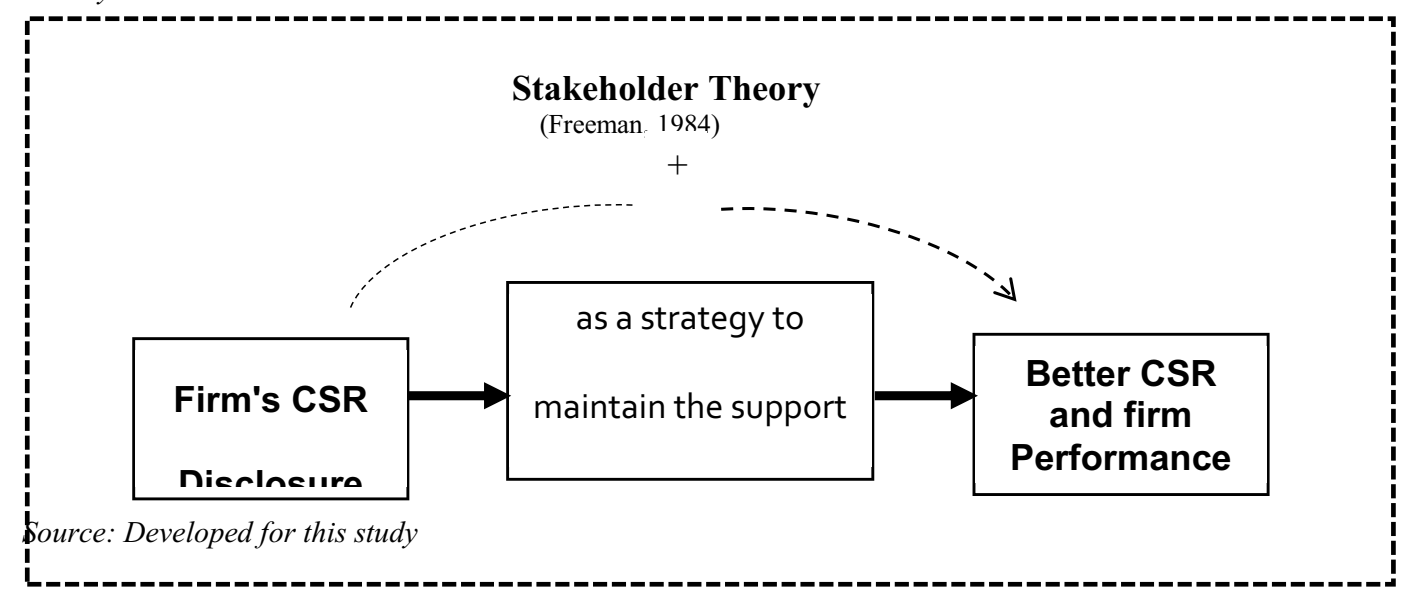

In other word, a firm's financial success is contingent on the ability to formulate and execute CSR strategy that manages effectively its relationships with stakeholders (Donaldson \& Preston, 1995) as the stakeholders have their rights to seek for information about how the firm is impacting on them (Deegan \& Unerman, 2006). Based on this perspective, Jones \& Nisbet (2011) emphasized that business is under pressure from their stakeholders to report its CSR activities because these parties want to protect their long term interests in the firm. Thus, reporting firm's CSR activities is a major element that can be engaged by the firm to manage the stakeholder in order to gain their support and approval.

In pursuing social responsibility, firms need to acquire both tangible and intangible resources that allow them to greater spending on CSR activities in order to differentiate themselves and increase their competitiveness (Russo \& Fouts, 1997; Schnietz \& Epstein, 2005). In conclusion, this selection is grounded in the belief that firm stakeholder relationships are the essential assets that managers must manage (Post, Preston \& Sachs, 2002) and the important role of stakeholders in addressing the issue of to whom a business should be accountable (Kakabase, Rozuel \& Lee-Davies, 2005).

\section{CONCLUSION}

CSR is understood to be the way firms integrate social, environmental and economic concerns into their business processes, decision making, strategy and also operations in a transparent and accountable manner, thereby establish better practices within the firm, create wealth and improve society (Linh \& Hieu, 2011). As such, the stakeholder theory is used as a basis to analyze those groups to whom the firm should be responsible and how far that scope of responsibility extends due to the fact that a firm's success is increasingly affected by stakeholders relationships (O'Riordan \& Fairbrass, 2008). Thus, practically, firms still need to continually make commitment in implementing the CSR since there is a strong relationships between firm's CSR practices and its stakeholders (Waddock \& Graves, 1997; Orlitzky et al., 2003; Ghelli, 2013; Abd-Mutalib et al., 2014). 


\section{REFERENCES}

Abd-Mutalib, H., Jamil, C.Z.M., \& Wan-Hussin, W.N. (2014). The Availability, Extent and Quality of Sustaiability Reporting by Malaysian Listed Firms: Subsequent to Manadatory Disclosure. Asian Journal of Finance \& Accounting 6(2), 239-260.

Ahamed, W., Suhazeli, W., Almsafir, M. K., \& AlSmadi, A. W. (2014). Does Corporate Social Responsibility Lead to Improve in Firm Financial Performance? Evidence from Malaysia.International Journal of Economics \& Finance, 6(3)

Amran, A. (2006). Corporate Social Reporting in Malaysia: An Institutional Perspective. Unpublished PhD Thesis. University of Malaya.

Amran, A., Zain, M. M., Sulaiman, M., Sarker, T., \& Ooi, S. K. (2013). Empowering Society for Better Corporate Social Responsibility (CSR): The case of Malaysia. Kajian Malaysia, 31(1), 57-78

Belkaoui, A.R. (2000). Accounting Theory, 4th edition, Academic Press, London

Caroll, A. B. (1979). A three-dimensional model of corporate social performance. Academic of Management Review, 4, 497-505.

Carroll, A., \& Shabana, K. (2010). The business case for corporate social responsibility: A review of concepts, research and practice. International Journal of Management Reviews, 12(1), 85-105. http://dx.doi.org/10.1111/j.1468-2370.2009.00275.x

Clarkson, M. (1995). A stakeholder framework for analyzing and evaluating corporate social performance. Academy of management Review, 20(1), 92-117.

Clifton, D. and Azlan Amran. (2010). The stakeholder approach: A sustainability perspective. Journal of Business Ethics 98(1): 121-136.

Cramer, J., \& Bergmans, F. (2003). Learning about corporate social responsibility : the Dutch experience. Amsterdam; Washington, DC: IOS Press

Deegan, C. \& Blomquist, C. (2006). Stakeholder influence on corporate reporting: An exploration of the interaction between WWF, Australia and the Australian minerals industry. Accounting, Organizations and Society, 31(4-5), 343-372.

Deegan, C. \& Unerman, J. (2006). Financial Accounting Theory, McGraw Hill, Berkshire

Ditlev-Simonsen, C. D., \& Midttun, A. (2011). What motivates managers to pursue corporate responsibility? a survey among key stakeholders. Corporate Social Responsibility and Environmental Management, 18, 25-38. doi: 10.1002/csr.237

D. M. DiSegni, M. Huly, and S. Akron, Corporate Social Responsibility, Environmental Leadership and Financial Performance, Social Responsibility Journal,11 (2015) 131148.

Donaldson, T. and Preston, L.E. (1995), “'The stakeholder theory of the corporation: concepts, evidence, and implications", Academy of Management Review, Vol. 20, pp. 65-91.

Dkhili, H., \& Ansi, H. (2012). The link between corporate social responsibility and financial 
performance: The case of Tunisian companies. Journal of Organizational Knowledge Management, 2(4), 20-12.

Elijido - Ten, E (2007) Applying stakeholder theory to analyze corporate environmental performance: Evidence from Australian listed companies. Asian Review of Accounting,Vol. 15(2) PP 164-184

Esa, E., \& Mohd Ghazali, (2012). Corporate social responsibility and corporate governance in Malaysian government-linked companies. Corporate Governance, 12(3), 292-305.

Freeman, R.E. (1984). Strategic management: A stakeholder approach. Boston: Pitman.

Freeman, I., \& Hasnaoui, A. (2010). The meaning of corporate social responsibility: The vision of four nations. Journal of Business Ethics, 100, 419-443.

Gill, A. (2008). Corporate governance as social responsibility: A research agenda. Berkeley Journal of International Law, 26 (2), 452-478.

Ghelli, C. (2013). Corporate social responsibility and social performance: An empirical evidence. Copenhagen Business School

Ghotb, H. (2011). Corporate Social Responsibility (CSR) in catering industry: The perception of diners and their buying behavior. Master diss., University of Malaya, Kuala Lumpur, Malaysia

Gray R. H., Owen D. L. and Adams C. (1996). Accounting and accountability, changes and challenges in corporate social and environmental reporting. Prentice Hall, Hemel Hempstead

Gyves, S, \& O.Higgins, E. (2008), .Corporate social responsibility: an avenue for sustainable benefit for society and the firm?., Society and Business Review, Vol. 3 No. 3, pp. 207-223.

Hamid, A F. Z., \& Atan, R. (2011). Corporate Social Responsibility by the Malaysian Telecommunication Firms. International Journal of Business and Social Science, 2(5) [Special Issue], 198-208.

Hopkins M. (1998) .The Planetary Bargain: Corporate Social Responsibility Comes of Age., Macmillan, London.

Jones, T. M. (1995). Instrumental stakeholder theory: A synthesis of ethics and economics. Academy of Management Review 20: 404-437.

Jones, B. \& Nisbet, P. (2011). Shareholder value versus stakeholder values: CSR and financialization in goal global food firms. Socio-Economic Review, 9, 287-314.

Kakabadse, K. N., Rozuel, C., \& Davis, L. (2005). Corporate Social Responsibility and Stakeholder Approach: A Conceptual Review. International Journal of Business Governance and Ethics, 1(4), 277-302.

Linh, N. T., \& Hieu, P. D. (2011). Impacts of Coprate Social Responsibility On The Financial Performance of The Firms. 1-38. 
L.J. Chen, A. Feldmann, O. Tang. (2015). The relationship between disclosures of corporate social performance and financial performance: Evidences from GRI reports in manufacturing industry, International Journal of Production Economics 1-12.

Murray, K, \& Vogel, C (1997), 'Using a Hierarchy-of-Effects Approach to Gauge the Effectiveness of Corporate Social Responsibility to Generate Goodwill Toward the Firm: Financial versus Nonfinancial Impacts', Journal Of Business Research, Vol. 38, Issue 2, pp. 141-159

McWilliams, A. and D. Siegel. (2001). Corporate social responsibility: A theory of the firm perspective. Academy of Management Review 25: 117-127.

Neal, R. \& Cochran, P. L. (2008). Corporate social responsibility, corporate governance, and financial performance: Lessons from finance. Business Horizons, 51, 535-540

Orlitzky, M, Schmidt, FL and Rynes, SL (2003), Corporate Social Responsibility and Financial Performance: a meta analysis ${ }^{e e}$, Organization Studies, vol. 24, pp. 403-411.

O'Riordan, L. and Fairbrass, J. (2008) 'CSR - Theories, Models and Concepts in Stakeholder Dialogue - A Model for Decision-Makers in the Pharmaceutical Industry’ Journal of Business Ethics 83(4), 754-758

Pop O., G. C. Dina, C. Martin (2011) Promoting the corporate social responsibility for a green economy and innovative jobs. Procedia Social and Behavioral Sciences 15 (2011) $1020-1023$

Post, J. E., Preston, L. E. and Sachs, S. (2002) "Managing the Extended Enterprise: The New Stakeholder View", California Management Review, Vol. 45 No. 1, pp. 6-28.

Raza, A., Ilyas, M. I., Rauf, R., \& Qamar, R. (2012). Relationship between Corporate Social Responsibility (CSR) and Corporate Financial Performance (CFP): Literature review approach. Elixir Financial Management, 46(9), 8404-8409.

Russo, M. and Fouts, P. (1997), .A resource-based perspective on corporate environmental performance and profitability., Academy of Management Journal, vol40, pp. 534-559.

R.M. Whalen, Corporate social responsibility and its relationship with financial performance, $\mathrm{PhD}$ thesis, Capella University, 2013

Schnietz, K., \& Epstein, M. (2005). Exploring the financial value of a reputation for corporate social responsibility during a crisis. Corporate Reputation Review, 7(4), 327-345.

Vormedal I, and Ruud A.( 2009). Sustainability reporting in Norway - an assessment of performance in the context of legal demands and sociopolitical drivers. Business Strategy and the Environment 18: 207-222.

Waddock, S.A., \& Graves, S.B. (1997). The corporate social performance-financial performance link. Strategic Management Journal, 18, 303-319. 
W. S. Lu, K. W. Chau, H. D. Wang, and W. Pan, A Decade's Debate on The Nexus between Corporate Social and Corporate Financial Performance: A Critical Review of Empirical Studies 2002-2011, Journal of Cleaner Production, 79 (2014) 195-206.

Zhu, Y.L. (2011). An Empirical Study on Corporate Social Responsibility and Corporate Profitability. Management Science and Industrial Engineering (MSIE), 650-652. 